\title{
Quantification of biogenic amines in fabrication steps of Gorgonzola-type cheese*
}

\section{Quantificação de aminas biogênicas nas etapas de fabricação do queijo tipo Gorgonzola}

\author{
Érica Barbosa Santos, ${ }^{* *}$ Carlos Adam Conte Júnior, ${ }^{* *}$ Robson Maia Franco, ${ }^{* * *}$ Viviane da Silva Gomes, ${ }^{* *}$ \\ Bárbara Brizola Rosa, ${ }^{* * * *}$ Môsar Lemos, ${ }^{* * *}$ Carlos Frederico Marques Guimarães, ${ }^{* * *}$ \\ Flávia Aline Andrade Calixto, ${ }^{* *}$ Adriana Cristina de Oliveira Silva***
}

\begin{abstract}
During the Gorgonzola-type cheese preparation there are proteolysis and lipolysis which may be influenced by the type of starter culture chosen. Six manufacturing steps were selected to identify which of them is most suitable for biogenic amines (BA) formation (1- milk, 2- lactic acid bacterial culture and fungus addition, 3- curd, 4- dry salting, 5- maturation at 30 days and maturation at 60 days); perform research on enterobacteria; accomplish the research of BA-producing bacteria (BAPB); detect and quantify the most abundant BA (putrescine, cadaverine, tyramine, histamine, spermidine and spermine) in the six steps of Gorgonzola cheese production and in bacterial isolates using high performance liquid chromatography and UV-Vis SPD/10AV detector and define if the presence of enterobacteria and BAPB would be correlated with BA production in this cheese. The bacterial culture used increased its log population by $7 \log$ cycles and reached its highest level in batch 2 during cheese maturation. There was a decrease in the enterobacterial population in 2 log cycles after 60 days of maturation in batch 1. Tyramine was the BA with the highest concentration $306.32 \mathrm{mg} . \mathrm{Kg}^{-1}$ quantified in step 6 (60 days maturation) in batch 1. Criterion is requiered in bacterial starter culture selection because it is a quality determinant factor in relation to BA production and more rigor in raw material selection.
\end{abstract}

Keywords: cromatography, starter culture, SPD/10AV UV-Vis detector, maturation, tyramine

\section{Resumo}

Durante a elaboração do queijo tipo Gorgonzola ocorre proteólise a partir das bactérias e dos fungos adicionados ao leite que podem levar a formação de aminas biogênicas (AB) neste tipo de queijo. Portanto, no presente estudo foi feito o acompanhamento com coleta de amostras em seis etapas na fabricação deste queijo para identificar em qual delas haveria maior formação de aminas biogênicas $(A B)$. As amostras coletadas em três diferentes lotes foram o leite cru (1), leite pasteurizado adicionado de cultura de bactérias ácido-láticas (2), massa coalhada (3), queijo após a etapa de salga seca (4), queijo após 30 dias de maturação (5) e queijo após 60 dias de maturação (6). Também foram realizadas a pesquisa de enterobactérias e bactérias ácido-láticas com característica capacidade de descarboxilação de aminoácidos e produção de aminas biogênicas (BPAB); detecção e quantificação da AB mais abundante (putrescina, cadaverina, tiramina, histamina, espermidina e espermina) nas seis etapas de fabricação do queijo tipo Gorgonzola e nos isolados bacterianos utilizando cromatografia líquida de alta eficiência e detector UV-Vis SPD/10AV e a verificação se a presença de enterobactérias e BPAB estariam correlacionadas com a produção de $A B$ nesse queijo. A cultura bacteriana utilizada cresceu aumentando em sete ciclos logarítmicos sua população e alcançou seu maior nível no lote 2 na etapa de maturação do queijo. Houve diminuição da população enterobactérias em 2 ciclos logarítmicos após 60 dias de maturação no lote 1. A tiramina foi a AB com concentração mais elevada $306,32 \mathrm{mg} \mathrm{Kg}^{-1}$ quantificada na etapa 6 (60 dias de maturação) no lote 1. É necessário dar mais atenção em duas etapas na elaboração dos queijos: mais critério na seleção da cultura bacteriana iniciadora por ser um fator determinante na qualidade em relação à produção de $A B$ e mais rigor na seleção da matéria-prima.

Palavras chaves: cromatografia, cultura iniciadora, detector SPD/10AV UV-Vis, maturação, tiramina

*Recebido em 29 de agosto de 2017 e aceito em 26 de junho de 2020.

**Postgraduate Program in Veterinary Medicine, Fluminense Federal University, Vital Brazil Filho, 64, CEP: 24230-340 Niterói, Rio de Janeiro, Brazil. Emails: ericaebs@hotmail.com, vivinutri_gomes@yahoo.com.br, flaviacalixto1@gmail.com

***Department of Food Technology, Veterinary Faculty, Fluminense Federal University, Vital Brazil Filho, 64, CEP: 24230-340 Niterói, Rio de Janeiro, Brazil. Emails: carlosconte@hotmail.com, robsonmf@vm.uff.br, mosarl@id.uff.br, fredmg@vm.uff.br, adrianasilva@id.uff.br and

****Graduate Student, Veterinary Faculty, Fluminense Federal University, Vital Brazil Filho, 64, CEP: 24230-340 Niterói, Rio de Janeiro, Brazil. Email: barbarabrizola8@gmail.com. 


\section{Introduction}

BA production in cheeses has frequently been associated to starter and non-starter lactic acid bacteria, such as Lactobacillus and Enterobacteriaceae, respectively (Herrero-Fresno et al., 2012). The species of many genera including Lactobacillus, Bacillus, Citrobacter, Clostridium, Escherichia, Klebsiella, Listeria, Photobacterium, Proteus, Pseudomonas, Salmonella, Shewanella, Shigella and Plesiomonas and lactic acid bacteria are capable of decarboxylating one or more types of amine (Papavergou et al., 2012). Many different genera and species of Gram-negative and positive bacteria have the ability to produce BA (Shirone et al., 2013).

In addition to bacteria, there are other factors that affect the BA formation and accumulation in cheeses, and the main ones are the availability of amino acids (and therefore, proteolytic activity) and the presence of bacteria with amino acid decarboxylation capacity. Other factors may also contribute to the formation of $\mathrm{BA}$ in the cheese, such as milk quality, $\mathrm{pH}$, salt concentration, water availability, temperature and duration of maturation and storage, lactic acid bacteria starter or non-starter, density and the presence of cofactors and amine catabolism (Spizzirri et al., 2013). It has been reported that conditions leading to accelerated or increased proteolysis may result in a significant increase of BA during cheese ripening (Buňková et al., 2013).

The most important BA found in cheeses are histamine, tyramine, putrescine and cadaverine, which originate from decarboxylase activities of specific amino acids of the cheese microbiota (Qureshi et al., 2013). According to Ladero et al. (2008), histamine is the most active BA and most frequently involved in food poisoning and the histamine concentrations found by them in 80 cheeses made from different types of milk and undergoing different ripening periods, detected at $41,25 \%$ of the samples, ranged from 20 to

\section{More than $1000 \mathrm{mg}$ per $\mathrm{Kg}$ of cheese.}

Due to these characteristics, cheese is among the foods that are most commonly implicated in histamine poisoning and tyramine toxicity (EFSA, 2011). Foods rich in tyramine, such as cheese, show a close relationship with migraine attacks and the toxic effects were termed cheese reactions (Schirone et al., 2013).

One of the cheeses widely consumed worldwide and in which the mass undergoes intense proteolytic action is Gorgonzola cheese, matured for 60 to 120 days by the bacteria Lactococcus spp. and Penicillium roqueforti, which grows internally in the cheese's mechanical gills (Gillot et al., 2017). Due to the strong proteolytic and lipolytic action that occurs in this type of cheese, it develops a pronounced flavor and aroma and also the presence of BA (histamine, tyramine, $\beta$-phenylethylamine, isopentyl, putrescine, cadaverine) (EL-SHEIKH et al. 2011). In the study presented by Gillot et al. (2017), it was observed that the free amino acids generated from the proteolysis were used in the formation of the biogenic amines by some bacteria with specific decarboxylation capacity.

Although there are scientific studies showing the presence of BA in different types of cheese, the food technology needs more precise information about which technological steps could characterize a greater favoring in the production of BA during Gorgonzola-type cheese elaboration.
Therefore, the objectives of this study were to identify in which stages of the production of Gorgonzola type cheese the greatest production of biogenic amines (BA) occurs; to detect which biogenic amines are produced in higher concentrations; detect the presence of acid-lactic bacteria with the characteristic of amino acid decarboxylation capacity and production of biogenic amines (BAPB) in cheese samples using specific means for Enterobacteria and lactic acid bacteria ( $L A B)$ and to determine whether the presence of Enterobacteriaceae, acid-lactic bacteria or other quality parameters are correlated with the production of biogenic amines in the cheese in question.

\section{Materials and Methods}

\section{Cultures}

In all three cheese batches elaboration, the bacterial culture was M $036 \mathrm{~L} 05$ and its composition included Lactococcus lactis subsp. lactis, Lactococcus lactis subsp. cremoris, Lactococcus lactis subsp. lactis biovar. Diacetylactis e Leuconostoc sp., and fungal culture of Penicillium roqueforti was PRN, both of $\operatorname{SACCO}^{\circledR}$.

\section{Production of the Gorgonzola-type cheese and collect- ing samples}

Gorgonzola-type cheeses were produced according to Moraes \& Freitas (1983) in the cheese section of the Milk Pilot Plant at a secondary school in São Gonçalo city, in the state of Rio de Janeiro, Brazil. Samples of milk, curds and cheese collected during the cheesemaking process were transported to the laboratory for analysis. For the milk, pre-sterilized glass bottles with $1 \mathrm{~L}$ capacity were used; for the curd and cheese samples, $500 \mathrm{~g}$ polyethylene packages were used, all in polystyrene boxes insulated on ice. For its production, the milk was standardized with $4.7 \%$ fat (adding cream), pasteurized in plate systems at $72-75^{\circ} \mathrm{C} \mathrm{/}$ $15-20$ seconds and cooled to $32^{\circ} \mathrm{C}$. The milk was then poured into $200 \mathrm{~L}$ tanks; $(0.5 \mathrm{~g} / 50 \mathrm{~L})$, fungal culture PRN $(0.5 \mathrm{~g} / 50$ $\mathrm{L})$, sodium chloride $(0.5 \mathrm{~g} / 50 \mathrm{~L})$, calcium chloride $(20 \mathrm{~g} / 100$ $\mathrm{L})$, a thermophilic starter culture After 40 minutes of standing, once the mixture was curdled, the curds were broken or diced (2.0-3.0 cm wide) The mixture was stirred slowly for $40 \mathrm{~min}$ at $36^{\circ} \mathrm{C}$, the temperature was raised to $43^{\circ} \mathrm{C}$ and stirring was continued until the desired consistency of the mass was reached ( $\pm 50 \mathrm{~min}$ ). After draining, the curd was hand-shaped and transferred to $2.0 \mathrm{Kg}$ molds in a circular shape and then allowed to stand to allow an additional loss. The cheese was stored in a maturation chamber $\left(8-12^{\circ} \mathrm{C}, 90-95 \%\right.$ of the weight of the cheese). After 15 days the cheeses were punched and large (copper) metal needles penetrated the cheeses to allow air to enter and thus allow the development of cultures previously introduced into the curd. The air creates ideal and natural conditions for the development of Penicillium roqueforti, which is responsible for the blue/ green shaft that makes Gorgonzola cheese so unique. Finally, the cheeses were submitted to a new verification to evaluate their quality characteristics, they were cut in two or more pieces and each piece was wrapped in raised aluminum foil and stored for up to 60 days at $4 \pm 1^{\circ} \mathrm{C}$. The cheese production was carried out three times (three batches) and the samples were collected in six different steps: step 1 (raw milk collection), step 2 (collection of pasteurized milk 
added from the dairy culture), step 3 (collection of the cheese), step 4 (cheese collection after dry salting), step 5 (cheese collection after 30 days of maturation) and step 6 (cheese collection after 60 days of maturation).

\section{Bacteriological Analysis}

The Purity of bacterial culture was tested using Litmus Milk (Davis, 1935).

The Research of Total Coliform was held the recommended by APHA (2001), in step 2 samples (collection of pasteurized milk added from the dairy culture) in order to check if the culture was free from other bacteria.

In the research for Potentially Biogenic Amine-Producing Bacteria by lactic acid bacteria in ripened cheeses, we used the method proposed by Stratton (1992) and Izquierdo et al. (2003). Ten grams of each sample was weighed and homogenized with $90 \mathrm{~mL}$ of $0.9 \%$ peptone water. From this dilution $\left(10^{-1}\right)$, serial dilutions to $10^{-12}$ were seeded in duplicate onto plates containing De Man, Rogosa and Sharpe (MRS) double-layer agar and incubated at $37^{\circ} \mathrm{C}$. Typical colonies were Gram-stained, and the bacterial morphology was observed by means of a stereoscopic microscope using incident and transmitted light. Biochemical tests for oxidase and catalase were also performed.

The capacity to produce the amines tyramine, cadaverine, histamine, putrescine, spermine and spermidine, typical pretested colonies were lifted from the MRS agar and transferred into four different tubes containing MRS broth, $37 \mathrm{mM}$ pyridoxine or vitamin B6, supplemented with $2 \%$ of each precursor aminoacid separately (first tube: tyrosine; second tube: lysine; third tube: I-histidine; fourth tube: ornithine) and incubated at $37^{\circ} \mathrm{C}$ for 24h. The tubes containing MRS broth, vitamin B6 and one of the four amino-acid precursors were tested separately for $\mathrm{pH}$ shift. All tubes were sent to the same method of extraction and derivatization for detection and quantification of BA by HPLC.

In the search for Potentially Biogenic Amine-Producing Bacteria by enterobacteria in ripened cheeses, we used the method proposed by Stratton (1992) and Izquierdo et al. (2003). Twenty five grams of each sample was weighed and homogenized with $225 \mathrm{~mL}$ of $0.1 \%$ peptone saline solution. From this dilution (10 $\left.{ }^{1}\right)$, serial dilutions to $10^{-8}$ were seeded in duplicate onto plates containing Violet Red Bile Glucose (VRBG) double-layer agar and incubated at $37^{\circ} \mathrm{C}$.

To determine the capacity to produce the amines tyramine, cadaverine, histamine, putrescine, spermine and spermidine, typical pre-tested colonies were lifted from the agar and transferred into four different tubes containing Brain Heart Infusion broth, $37 \mathrm{mM}$ pyridoxine or vitamin B6, supplemented with $2 \%$ of each precursor amino-acid separately (first tube: tyrosine; second tube: lysine; third tube: I-histidine; fourth tube: ornithine) and incubated at $35-37^{\circ} \mathrm{C}$ for $24 \mathrm{~h}$. The tubes containing $\mathrm{BHI}$ broth, vitamin $\mathrm{B}_{6}$ and one of the four amino-acid precursors were tested separately for $\mathrm{pH}$ shift. All tubes were referred by the same method of extraction and derivatization for detection and quantification of BA by HPLC.

\section{Biogenic amine determination by HPLC}

Preparation of Standards. Standards of tyramine $\left(\mathrm{C}_{8} \mathrm{H}_{11} \mathrm{NO}\right)$, histamine $\left(\mathrm{C}_{5} \mathrm{H}_{9} \mathrm{~N}_{3}\right)$, putrescine $\left(\mathrm{C}_{4} \mathrm{H}_{12} \mathrm{~N}_{2}\right)$, cadaverine $\left(\mathrm{C}_{5} \mathrm{H}_{14} \mathrm{~N}_{2}\right)$, spermidine $\left(\mathrm{C}_{14} \mathrm{H}_{47} \mathrm{~N}_{6} \mathrm{O}_{12} \mathrm{P}_{3}\right)$, and spermine $\left(\mathrm{C}_{10} \mathrm{H}_{26} \mathrm{~N}_{4}\right)$ were purchased from Sigma-Aldrich ${ }^{\circledR}$ (St. Louis, MO, USA). Stock solutions for each amine $\left(40 \mathrm{\mu gL}^{-1}\right)$ were prepared in $0.1 \mathrm{~N} \mathrm{HCl}$ and stored at $4 \pm 1{ }^{\circ} \mathrm{C}$ (Cunha, 2012; Lázaro, 2013).

Sample Preparation. For BA extraction, $5 \mathrm{~g}$ of minced cheese was homogenized with $5 \mathrm{~mL}$ of $5 \%$ perchloric acid (Cunha et al., 2012; Lázaro et al., 2013).

Chromatographic conditions. The samples of cheese and the tubes containing bacterial strains with possible potential to produce BA were tested by this method. The chromatographic system consisted of a LC/10AS pump coupled to a SPD/10AV UV-Vis detector and a C-R6A chromatopack integrator (Shimadzu, Kyoto, Japan). BA separations were performed on a Teknokroma Tracer Extrasil ODS2 $(15 \times 0.46 \mathrm{~cm}$ id., $5 \mu \mathrm{m})$ column equipped with a Supelco Ascentis C18 $(2 \times 0.40 \mathrm{~cm}$ id., $5 \mu \mathrm{m})$ guard column, under isocratic conditions (Lázaro et al., 2013).

\section{Statistical Analysis}

Data were analyzed by unidirectional ANOVA using the XL STAT $^{\circledR} 2015$ for Windows. The averages were compared by the Tukey test $(p<0.05)$ to verify significant differences between the independent and dependent variables; with more than one level of significance ( $p<0.05$ and $p<0.01$ ). The Pearson Correlation Coefficient was also used to establish a correlation between bacterial growth and BA formation.

\section{Results e Discussion}

\section{Bacteriological Analysis}

Through the Purity Test of Cultures it was possible to observe that all samples containing cultured bacteria were pure and perfectly viable with all clots formed homogeneously and with a perfect color change from lilac to light pink. The Total Coliforms Survey was performed in the samples from step 2, where the cultures were added in the three batches and all the results were negative. The lactic acid bacteria of the bacterial culture used are immediately used and, after weighing under sterile conditions, were diluted in pasteurized milk and immediately added to the tank $(0.5 \mathrm{~g} / 50 \mathrm{~L})$. Table 1 shows the amount of lactic acid bacteria present in the different stages. Milk initially had a population of lactic bacteria (2.93 Log CFU.g-1); so in the first two manufacturing steps the amount of remaining $\mathrm{LAB}$ from pasteurization added to the added $L A B$ resulted in increase to 9 Log cycles in step 6.

It is verified that even in raw milk, have already exists lactic bacteria according to Hermanns et al. (2013) who found a high bacterial count in the samples of their study; these bacterias and others of another origin (from skin, from intestines and any other origin) denoting to be related to the inadequate conditions of hygiene, transport, manipulation and milk refrigeration; factors that impose the need for greater participation of quality control and milk pasteurization as a mandatory measure of food safety in milk consumption.

Only after step 3 (curd) in batch 3 it was observed a further development of the bacteria added to the milk. In step 6 , there is an increase of seven Log cycles to its population (ranging from 2.74 Log CFU.g ${ }^{-1}$ to $9.45 \mathrm{Log} \mathrm{CFU.g}^{-1}$ ) and reached its highest value in step 6 of batch 2 (9.45 Log CFU.g $\left.{ }^{-1} ; p<0.05\right)$, in other 
Table 1: Lactic-acid bacteria results (Log CFU.g-1) in different steps of Gorgonzola-type production cheese arranged in order of date

\begin{tabular}{cccc}
\hline STEPS & BATCH 1 & BATCH 2 & BATCH 3 \\
\hline 1 & $2.93^{\mathrm{e}} \pm 0.10$ & $2.74^{\mathrm{e}} \pm 0.15$ & $4.20^{\mathrm{e}} \pm 1.27$ \\
2 & $3.14^{\mathrm{e}} \pm 0.03$ & $3.65^{\mathrm{e}} \pm 0.65$ & $4.87^{\mathrm{de}} \pm 0.27$ \\
3 & $3.10^{\mathrm{e}} \pm 0.21$ & $3.71^{\mathrm{e}} \pm 2.46$ & $5.08^{\mathrm{cde}} \pm 0.47$ \\
4 & $3.64^{\mathrm{e}} \pm 1.33$ & $4.59^{\mathrm{de}} \pm 0.30$ & $5.01^{\text {cde }} \pm 0.45$ \\
5 & $6.94^{\text {bcd }} \pm 0.89$ & $6.92^{\text {bcd }} \pm 0.07$ & $7.45^{\text {abc }} \pm 0.42$ \\
6 & $9.26^{\text {ab }} \pm 0.02$ & $9.45^{\mathrm{a}} \pm 0.08$ & $9.14^{\text {ab }} \pm 0.04$
\end{tabular}

Means of determinations with standard deviation. Values in the same row with different letters are significantly different $(p<0.05)$. Steps: $(1)$ milk, $(2)$ culture addition, (3) curd, (4) dry salting, (5) 30 days of maturation, and (6) 60 days of maturation.

words, after 60 days of maturation. The lower development of these bacteria can be observed from step 1 where they are in LAG phase. In step 2, due to the pasteurization treatment, the time-temperature binomial reduced the lactic acid bacteria population. LOG phase can be observed from step 2 to step 6. Stationary and declining phases were not observed in this study. Up to the maturation stage, the growth was more discrete because bacteria were in recovery process after the heat treatment, and from step 5, products of the biochemical stage of maturation are available to accelerate the bacterial growth process (RODRÍGUEZ et al., 2013; DANNENHAUER, 2010). Due to the high initial loading of contaminating bacteria (step 1), milk pasteurization process was insufficient to eliminate enterobacteria that remained in cheeses after 60 days of maturation (Table 2), which is not usually expected, according to Dahl et al. al. (2000). After pH decrease, occurred in these types of cheese, there is acidification of the medium and this fact interferes in the population of this bacterial genus due to its sensitivity to the lactic acid produced during the fermentation during the maturation stage (GOMES et al., 2014).

Table 2: Enterobacteria results (Log CFU. ${ }^{-1}$ ) in different steps of Gorgonzola-type cheese production arranged in order of date

\begin{tabular}{|c|c|c|c|}
\hline STEPS & BATCH 1 & ВАТCH 2 & ВАТCH 3 \\
\hline 1 & $6.60^{\mathrm{e}} \pm 0.10$ & $4.29^{\mathrm{e}} \pm 1.38$ & $5.17^{\mathrm{e}} \pm 0.10$ \\
\hline 2 & $6.83^{\mathrm{e}} \pm 0.12$ & $3.45^{\mathrm{e}} \pm 1.27$ & $6.14^{\mathrm{de}} \pm 0.03$ \\
\hline 3 & $6.61^{\mathrm{e}} \pm 0.08$ & $3.77^{\mathrm{e}} \pm 1.27$ & $6.76^{\mathrm{cde}} \pm 0.02$ \\
\hline 4 & $5.64^{\mathrm{e}} \pm 0.13$ & $3.60^{\mathrm{de}} \pm 1.17$ & $6.84^{\mathrm{cde}} \pm 0.07$ \\
\hline 5 & $5.27^{\mathrm{bcd}} \pm 0.31$ & $3.53^{\text {bcd }} \pm 1.15$ & $5.68^{\mathrm{abc}} \pm 0.14$ \\
\hline 6 & $4.11^{\mathrm{ab}} \pm 0.08$ & $3.42^{\mathrm{a}} \pm 1.14$ & $4.52^{a b} \pm 0.34$ \\
\hline
\end{tabular}

Means of determinations with standard deviation. Values in the same row with differen letters are significantly different ( $p<0.05)$. Steps: (1) milk, (2) culture addition, (3) curd, (4) dry salting, (5) 30 days of maturation, and (6) 60 days of maturation.
In general, enterobacterial population decrease after 60 days of maturation (step 6) was observed in all batches relative to the initial stages (change from 6.84 Log CFU. g $^{-1}$ to 3.42 Log UFC. $\mathrm{g}^{-1}$ ); however, this behavior was more evident and larger in batch 1 where there was a 2 Log cycles reduction in this bacterial genus population (from $6.60 \mathrm{Log}$ CFU.g ${ }^{-1}$ to $4.11 \mathrm{Log}$ CFU. g $^{-1}$ (Table 2). Serio et al. (2006) observed $10^{3}$ CFU. $g^{-1}$ and $10^{5}$ CFU. . $^{-1}$ (summer and winter, respectively) after 15 days of maturation and $10^{2} \mathrm{CFU} . \mathrm{g}^{-1}$ enterobacteria after 60 days of maturation for Pecorino Abruzzese cheese; Diezhandino et al. (2015) found much lower counts (0.43 Log CFU.g $\left.{ }^{-1}\right)$ and after the 60-day period, there was no enterobacteria detection in cheeses.

Both lactic acid bacteria from the culture and enterobacteria populations remained high at 60 days of maturation, their genotypes and others may have had a direct participation in the stimulation of BA production, since these two groups have this capacity. For 60 days, there was enough time, all the substrates and biochemical reactions in the cheese so that the notorious formation of BA was observed. According to Diezhandino et al. (2015), any value above zero is considered high because, with 60 days of maturation, enterobacteria can not be found, according to the literature. From a colony forming unit, production of BA can already be observed if the bacteria have decarboxylation capacity and have free amino acids at disposal.

\section{Biogenic Amines \\ Cheeses.}

Following the information contained in Table 3, from step 1 it was observed that some BA were already detected and this was due to the fact that the raw material arrived with a high level of contamination and the bacteria had already started the BA formation process. In the three batches only spermidine was not observed in step 1. Milk also contains biogenic substances and among these bioactive substances are the BA and polyamines that are present in milk and its derivatives (GALITSOPOULOU et al. 2015). Schirone et al. (2013), in analyzes of Pecorino cheeses, made from sheep's milk, raw and pasteurized, found a total of 266.7 to $5860.6 \mathrm{mg} . \mathrm{Kg}^{-1}$ of BA in cheeses made from raw milk and from 10.3 to $582.4 \mathrm{mg}^{\mathrm{Kg}}{ }^{-1}$ in pasteurized milk.

In step 2 (addition of culture to pasteurized milk), where there was addition of the culture containing Lactococcus lactis subsp. lactis, Lactococcus lactis subsp. cremoris, Lactococcus lactis subsp. lactis biovar. Diacetylactis and Leuconostoc sp., there was a discrete, but increasing formation of BA by the bacterial species known to form these substances.

The types and contents of BA present in fermented dairy products vary with raw material, the type of product, the maturation/fermentation time, the starter culture strains, the proteolytic activity and the manufacturing conditions (PRIYADARSHANI; RAKSHIT, 2011).

The step 2 results are in agreement with the amount of BA found in other dairy products (ANDIC et al., 2010; COSTA et al., 2015; ÖZDESTAN; ÜREN, 2010). 
Table 3 shows that in the cheese samples from batch 1 only tyramine was detected at all manufacture stages and its maximum result was at stage 6 , at 60 days of maturation (306.32 mg. $\mathrm{Kg}^{-1}$; significantly higher $\mathrm{p}<0.001$ ). In batches 2 and 3 no cadaverine and spermidine were detected, but spermine, histamine, putrescine and tyramine were detected. In batch 2 histamine was the BA with highest value $\left(65.46 \mathrm{mg} . \mathrm{Kg}^{-1}\right.$; significantly higher $\mathrm{p}<0.001)$ and in batch 3 was tyramine $(243.62$ $\mathrm{mg} . \mathrm{Kg}^{-1}$; significantly higher $\left.\mathrm{p}<0.001\right)$, both in step 6 .

According to Montanha (2016), the main agents responsible for proteolysis during cheese maturation (Table 3, step 3 - curd) are endogenous milk enzymes, coagulant residue retained in the rennet after manufacture and the proteolytic enzymes of precursor bacteria and not precursors. These biochemical transformations provide BA precursor substances (RASOVIC et al., 2017) and will be used from stage 4 (Table 3, dry salting).

In step 4 (Table 3, dry salting), salt levels are responsible for retarding the growth of $L A B$ and aid in the control of bitter taste (MISTRY, 2007; RAMÍREZ-NAVAS, 2017). Thus, by retarding the growth of some bacteria, the production of BA remains unobtrusive.

In steps 5 and 6 (Table 3), which are related to maturation, values are very close to those found by Cunha et al. (2012) who worked with similar cheeses and maturation time in the production of Gouda, Prato and Muçarela cheeses and found for tyramine $361.19 \mathrm{mg} . \mathrm{Kg}^{-1}, 152.91 \mathrm{mg} . \mathrm{Kg}^{-1}$ and $96.28 \mathrm{mg} . \mathrm{Kg}^{-1}$, respectively.

In addition to the aforementioned factors, the thermal treatment used (rapid pasteurization) was not enough to reduce the contaminant bacterial count in a satisfactory way, and with that, the subsequent production of BA by these contaminating bacteria and by the bacteria of the culture was quite accentuated after the main step of BA formation that is maturation - steps 5 and 6. This fact was most evident in step 6 (Table 3 ), at 60 days of maturation, where highest values for BA were quantified. Except to two quantifications (spermine: $4.78 \mathrm{mg} . \mathrm{Kg}^{-1}$ and putrescine: $4.96 \mathrm{mg} \cdot \mathrm{Kg}^{-1}$ ), all other concentrations are capable of causing food poisoning.

Del Rio et al. (2017) argue that tyramine and histamine are the BA most frequently found in high concentrations in foods and show synergistic toxicity to intestinal cells in culture. They may even appear together in toxic concentrations. Through its results, it was possible to observe that histamine, in concentrations below the legal limit, increases the cytotoxicity of tyramine in concentrations frequently reached in some foods. Tyramine and histamine synergistic cytotoxicity should be taken into account when establishing legal limits to ensure consumer safety. Tyramine is the BA most commonly detected in fermented dairy products, since many lactic acid bacteria can produce microbial tyrosine decarboxylase (BUŇKOVÁ et al., 2010), which explains the high tyramine values found in this study.

Law and Tamime (2010) observed that the bacteria of Enterobacteriaceae family are generally implicated in the formation of cadaverine, as well as those of the genus Pseudomonas spp. are considered responsible by putrescine formation. Since putrescina is precursor of spermine, which in turn is precursor of spermidine; this explains the increase in spermine from batches 2 and 3 in Table 3.

Some countries stipulate minimum doses of tyramine ingestion, but Brazil has no legislation for bioactive amines contamination (RIGUEIRA, 2010).

Table 3: Distribution of six biogenic amines concentration $\left(\mathrm{mg} \cdot \mathrm{Kg}^{-1}\right)$ detected in different steps of Gorgonzola-type cheese production

\begin{tabular}{|c|c|c|c|c|c|c|c|}
\hline \multirow{2}{*}{ LOTES } & \multirow{2}{*}{$\mathbf{A B}$} & \multicolumn{6}{|c|}{ ETAPAS } \\
\hline & & 1 & 2 & 3 & 4 & 5 & 6 \\
\hline \multirow{6}{*}{1} & cadaverina & n.d. & n.d. & n.d. & n.d. & n.d. & n.d. \\
\hline & espermidina & n.d. & n.d. & n.d. & n.d. & n.d. & n.d. \\
\hline & espermina & n.d. & n.d. & n.d. & n.d. & n.d. & n.d. \\
\hline & histamina & n.d. & n.d. & n.d. & n.d. & n.d. & n.d. \\
\hline & putrescina & n.d. & n.d. & n.d. & n.d. & n.d. & n.d. \\
\hline & tiramina & $0.46^{\mathrm{d}} \pm 6.29$ & $0.49^{\mathrm{d}} \pm 0.07$ & $2.68^{\mathrm{d}} \pm 0.07$ & $31.58^{c} \pm 0.42$ & $54.06^{b} \pm 6.89$ & $306.32^{\mathrm{a}} \pm 1.39$ \\
\hline \multirow{6}{*}{2} & cadaverina & n.d. & n.d. & n.d. & n.d. & n.d. & n.d. \\
\hline & espermidina & n.d. & n.d. & n.d. & n.d. & n.d. & n.d. \\
\hline & espermina & $0.71^{b} \pm 0.67$ & $0.77^{b} \pm 1.16$ & $0.78^{b} \pm 1.16$ & $2.12^{\mathrm{ab}} \pm 3.08$ & $10.92^{\mathrm{ab}} \pm 4.73$ & $17.73^{\mathrm{a}} \pm 13.02$ \\
\hline & histamina & $0.93^{\mathrm{a}} \pm 0.77$ & $1.03^{a} \pm 0.75$ & $2.73^{\mathrm{a}} \pm 4.23$ & $6.74^{\mathrm{a}} \pm 5.37$ & $16.61^{\mathrm{a}} \pm 0.32$ & $65.46^{\mathrm{a}} \pm 24.96$ \\
\hline & putrescina & $0.01^{\mathrm{a}} \pm 0.01$ & $0.03^{a} \pm 0.04$ & $0.03^{\mathrm{a}} \pm 0.04$ & $3.79^{\mathrm{a}} \pm 6.08$ & $3.85^{a} \pm 6.12$ & $4.96^{\mathrm{a}} \pm 2.54$ \\
\hline & tiramina & $4.03^{c} \pm 6.29$ & $4.19^{c} \pm 6.49$ & $9.73^{c} \pm 0.07$ & $28.26^{b} \pm 1.43$ & $37.48^{\mathrm{ab}} \pm 1.39$ & $46.56^{\mathrm{a}} \pm 3.57$ \\
\hline \multirow{6}{*}{3} & cadaverina & n.d. & n.d. & n.d. & n.d. & n.d. & n.d. \\
\hline & espermidina & n.d. & n.d. & n.d. & n.d. & n.d. & n.d. \\
\hline & espermina & $0.02^{b} \pm 0.01$ & $0.02^{b} \pm 0.01$ & $0.04^{b} \pm 0.02$ & $0.06^{c} \pm 0.04$ & $1.72^{\mathrm{ab}} \pm 0.36$ & $4.78^{\mathrm{a}} \pm 4.13$ \\
\hline & histamina & $0.56^{b} \pm 0.94$ & $1.03^{b} \pm 0.75$ & $2.51^{\mathrm{b}} \pm 0.97$ & $8.99^{b} \pm 7.79$ & $9.61^{b} \pm 8.27$ & $54.36^{\mathrm{a}} \pm 35.40$ \\
\hline & putrescina & $0.05^{\mathrm{a}} \pm 0.01$ & $1.19^{\mathrm{a}} \pm 0.07$ & $3.76^{\mathrm{a}} \pm 6.52$ & $4.59^{\mathrm{a}} \pm 7.96$ & $40.08^{\mathrm{a}} \pm 46.68$ & $40.54^{\mathrm{a}} \pm 46.90$ \\
\hline & tiramina & $0.78^{c} \pm 1.16$ & $9.08^{c} \pm 6.89$ & $9.23^{c} \pm 8.78$ & $32.67^{b} \pm 2.11$ & $33.55^{b} \pm 1.14$ & $243.62^{a} \pm 2.86$ \\
\hline
\end{tabular}

Means of determinations with standard deviation. Values in the same rows with different letters are significantly different ( $p$ < 0.05). Steps: (1) milk, (2) culture addition, (3) curd, (4) dry salting, (5) 30 days of maturation, and (6) 60 days of maturation. Legend: BA - Biogenic Amine; n.d. - not detected. 


\section{Enterobacteria Plate Isolated}

As with cheeses, it was also during the maturation stages (30 and 60 days) that there was a higher concentration of BA in the isolates from the enterobacteria growth plates. Most of the quantifications in step 6 are above the limit considered acceptable for human intake (Table 4). All samples had a total count above <10 CFU/g, the maximum limit established by the Ministry of Agriculture, Livestock and Supply - MAPA (BRASIL, 2003).

In Table 4, it can be observed that in all batches six BA were detected, except in steps 1 and 2 of batch 3 , in which no cadaverine was detected. In batch 1 , the three BA that were detected at the highest level $(p<0.05)$ were putrescine (413.47 mg. $\left.\mathrm{Kg}^{-1}\right)$, histamine (209.77 mg. $\mathrm{Kg}^{-1}$ ) and tyramine $\left(92,23 \mathrm{mg} \cdot \mathrm{Kg}^{-1}\right)$ in this order. In batch 2 , the three BA with highest concentrations $(p<0.05)$ were putrescine $(457.28$ $\left.\mathrm{mg} \cdot \mathrm{Kg}^{-1}\right)$, cadaverine (82.96 $\mathrm{mg} . \mathrm{Kg}^{-1}$ ) and spermidine (61.08 $\mathrm{mg}^{\mathrm{Kg}} \mathrm{K}^{-1}$ ). In batch 3 , the three BA with higher concentrations $(p<0.05)$ were putrescine $\left(252.10 \mathrm{mg}^{\mathrm{Kg}} \mathrm{Kg}^{-1}\right)$, cadaverine (19.48 mg. $\mathrm{Kg}^{-1}$ ) and histamine $\left(7.18 \mathrm{mg} . \mathrm{Kg}^{-1}\right)$. Although enterobacteria population decreased during maturation process, the surviving bacteria of this genus continued contributing to increase BA concentration, for example, in the case of putrescine from the three batches, which presented higher values (413, $47 \mathrm{mg} \mathrm{Kg}^{-1}, 457.28 \mathrm{mg} \mathrm{Kg}^{-1}$ and 252.10 mg. $\mathrm{Kg}^{-1}$, in batches 1, 2 and 3 respectively, all in step 6 (Table 4). Through the Pearson's correlation test it was possible to observe a strong correlation $(\rho=0.8$; positive) between the bacteria of the present study and the formation of BA. It means a perfect correlation $(\rho=1)$ between the two variables, since both increase proportionally.

\section{Lactic-Acid Bacteria Plate Isolated}

As with isolates from enterobacteria growth plates, it was also during the maturation steps (30 and 60 days) that there was a higher concentration of BA in the isolates from the lactic acid bacteria growth plates. Four quantifications in step 6 are above the limit taken as acceptable for human intake (Table 5).

In all batches six BA were detected, except in steps 2 and 4 of batch 1 and step 1 of batch 2, where no cadaverine was detected (Table 5). In batch 1, the three BA detected at the highest levels $(p<0.05)$ were tyramine $\left(121.58 \mathrm{mg} . \mathrm{Kg}^{-1}\right)$, putrescine $(4.41$ $\left.\mathrm{mg} . \mathrm{Kg}^{-1}\right)$ and histamine $\left(3.24 \mathrm{mg} . \mathrm{Kg}^{-1}\right)$ respectively. In batch 2 , the three BA with higher concentrations $(p<0.05)$ were putrescine (41.52 mg. Kg $\left.{ }^{-1}\right)$, tyramine (34.69 mg. Kg $\left.{ }^{-1}\right)$ and histamine $(2.87$ mg. $\left.\mathrm{Kg}^{-1}\right)$. In batch 3 , the three BA with highest levels $(p<0.05)$ were tyramine $\left(9.59 \mathrm{mg} . \mathrm{Kg}^{-1}\right)$, histamine $\left(0.56 \mathrm{mg} . \mathrm{Kg}^{-1}\right)$ and spermine $\left(0.20 \mathrm{mg} \cdot \mathrm{Kg}^{-1}\right)$.

Cunha et al. (2002) reported that highest values of putrescine, cadaverine, tyramine, histamine and spermidine were 44.10 mg. Kg-1, 16.18 mg. Kg ${ }^{-1}, 361.19$ mg. Kg ${ }^{-1}, 79.13$ mg. $\mathrm{Kg}^{-1}, 0.25$ $\mathrm{mg} \cdot \mathrm{Kg}^{-1}$, respectively. Tyramine and histamine values are higher than this present study values.

Izquierdo et al. (2003) quantified histamine in Parmesan type cheese (151,65 mg. Kg ${ }^{-1}$ ), Manchego (100.07 mg. Kg ${ }^{-1}$ ) and Year (113.32 $\left.\mathrm{mg} . \mathrm{Kg}^{-1}\right)$ using the same bacterial isolation method and

Table 4: Distribution of biogenic amines concentration $\left(\mathrm{mg} . \mathrm{Kg}^{-1}\right)$ detected in enterobacteria plate isolated from steps of Gorgonzola-type cheese production

\begin{tabular}{|c|c|c|c|c|c|c|c|}
\hline \multirow{2}{*}{ BATCHES } & \multirow{2}{*}{ BA } & \multicolumn{6}{|c|}{ STEPS } \\
\hline & & 1 & 2 & 3 & 4 & 5 & 6 \\
\hline \multirow{6}{*}{1} & cadaverina & $1.69^{a} \pm 1.63$ & $1.79^{\mathrm{a}} \pm 2.95$ & $3.29^{\mathrm{a}} \pm 4.11$ & $3.41^{\mathrm{a}} \pm 1.97$ & $11.50^{\mathrm{a}} \pm 14.95$ & $17.12^{\mathrm{a}} \pm 27.79$ \\
\hline & espermidina & $0.01^{\mathrm{a}} \pm 0.01$ & $0.66^{\mathrm{a}} \pm 1.12$ & $2.08^{\mathrm{a}} \pm 0.07$ & $2.32^{\mathrm{a}} \pm 3.99$ & $7.49^{\mathrm{a}} \pm 12.69$ & $9.18^{\mathrm{a}} \pm 15.57$ \\
\hline & espermina & $1.73^{\mathrm{a}} \pm 1.41$ & $2.10^{\mathrm{a}} \pm 0.10$ & $2.20^{\mathrm{a}} \pm 3.52$ & $4.28^{\mathrm{a}} \pm 5.61$ & $16.51^{\mathrm{a}} \pm 8.57$ & $27.70^{a} \pm 16.62$ \\
\hline & histamina & $0.06^{a} \pm 0.09$ & $0.30^{\mathrm{a}} \pm 0.20$ & $2.28^{\mathrm{a}} \pm 2.27$ & $20.37^{\mathrm{a}} \pm 20.24$ & $100.20^{a} \pm 169.82$ & $209.77^{\mathrm{a}} \pm 344.52$ \\
\hline & putrescina & $0.24^{b} \pm 0.06$ & $0.25^{b} \pm 0.11$ & $2.09^{b} \pm 1.51$ & $2.38^{b} \pm 1.79$ & $58.49^{\mathrm{ab}} \pm 101.13$ & $413.47^{\mathrm{a}} \pm 358.59$ \\
\hline & tiramina & $1.11^{b} \pm 1.41$ & $1.42^{b} \pm 0.81$ & $17.72^{a b} \pm 22.89$ & $928.20^{\mathrm{ab}} \pm 43.00$ & $0 \quad 45.70^{a b} \pm 39.29$ & $92.23^{a} \pm 31.56$ \\
\hline \multirow{6}{*}{2} & cadaverina & $0.09^{\mathrm{a}} \pm 0.10$ & $1.10^{\mathrm{a}} \pm 1.06$ & $1.18^{\mathrm{a}} \pm 1.23$ & $5.33^{\mathrm{a}} \pm 0.87$ & $25.69^{\mathrm{a}} \pm 22.59$ & $82.96^{\mathrm{a}} \pm 71.91$ \\
\hline & espermidina & $0.03^{b} \pm 0.01$ & $0.04^{b} \pm 0.01$ & $0.05^{b} \pm 0.03$ & $0.21^{b} \pm 0.07$ & $60.74^{\mathrm{a}} \pm 1.56$ & $61.08 \mathrm{a} \pm 1.71$ \\
\hline & espermina & $0.11^{\mathrm{a}} \pm 0.12$ & $0.82^{\mathrm{a}} \pm 1.36$ & $1.01^{\mathrm{a}} \pm 0.84$ & $1.52^{\mathrm{a}} \pm 0.71$ & $1.63^{\mathrm{a}} \pm 0.68$ & $2.17^{\mathrm{a}} \pm 0.64$ \\
\hline & histamina & $0.09^{\mathrm{a}} \pm 0.05$ & $0.46^{\mathrm{a}} \pm 0.61$ & $0.52^{\mathrm{a}} \pm 0.50$ & $0.86^{a} \pm 1.47$ & $11.65^{\mathrm{a}} \pm 12.80$ & $27.78^{a} \pm 47.92$ \\
\hline & putrescina & $34.16^{c} \pm 29.59$ & $50.11^{c} \pm 0.17$ & $151.32^{\mathrm{b}} \pm 79.03$ & $3164.85^{b} \pm 2.18$ & $398.73^{\mathrm{a}} \pm 9.61$ & $457.28^{a} \pm 19.98$ \\
\hline & tiramina & $0.10^{\mathrm{a}} \pm 0.01$ & $0.10^{\mathrm{a}} \pm 0.04$ & $0.13^{\mathrm{a}} \pm 0.01$ & $0.14^{\mathrm{a}} \pm 0.05$ & $1.15^{\mathrm{a}} \pm 0.08$ & $1.18^{\mathrm{a}} \pm 0.01$ \\
\hline \multirow{6}{*}{3} & cadaverina & n.d. & n.d. & $0.01^{\mathrm{a}} \pm 0.01$ & $0.01^{\mathrm{a}} \pm 0.01$ & $18.16^{\mathrm{a}} \pm 15.69$ & $19.48^{\mathrm{a}} \pm 16.87$ \\
\hline & espermidina & $0.01^{\mathrm{a}} \pm 0.01$ & $0.02^{\mathrm{a}} \pm 0.01$ & $0.02^{\mathrm{a}} \pm 0.02$ & $0.02^{\mathrm{a}} \pm 0.02$ & $0.03^{\mathrm{a}} \pm 0.01$ & $0.11^{\mathrm{a}} \pm 0.11$ \\
\hline & espermina & $0.03^{\mathrm{a}} \pm 0.01$ & $0.04^{\mathrm{a}} \pm 0.01$ & $0.04^{\mathrm{a}} \pm 0.01$ & $0.07^{\mathrm{a}} \pm 0.01$ & $0.20^{\mathrm{a}} \pm 0.15$ & $0.88^{\mathrm{a}} \pm 1.41$ \\
\hline & histamina & $0.01^{b} \pm 0.01$ & $0.06^{b} \pm 0.04$ & $0.92^{b} \pm 0.16$ & $0.92^{b} \pm 1.57$ & $7.09^{\mathrm{a}} \pm 0.08$ & $7.19^{\mathrm{a}} \pm 0.11$ \\
\hline & putrescina & $57.38^{\mathrm{a}} \pm 1.19$ & $69.08^{\mathrm{a}} \pm 33.16$ & $159.65^{a} \pm 3.79$ & $175.03^{a} \pm 52.94$ & $4250.53^{a} \pm 215.46$ & $252.10^{a} \pm 216.74$ \\
\hline & tiramina & $0.02^{b} \pm 0.01$ & $0.02^{\mathrm{b}} \pm 0.01$ & $0.06^{\mathrm{ab}} \pm 0.01$ & $0.10^{\mathrm{ab}} \pm 0.02$ & $0.14^{\mathrm{ab}} \pm 0.01$ & $0.18^{\mathrm{a}} \pm 0.13$ \\
\hline
\end{tabular}

Means of determinations with standard deviation. Values in the same rows with different letters are significantly different ( $p$ < 0.05). Steps: (1) milk, (2) culture addition, (3) curd, (4) dry salting, (5) 30 days of maturation, and (6) 60 days of maturation. Legend: BA - Biogenic Amine; n.d. - not detected. 
Table 5: Distribution of biogenic amines concentration $\left(\mathrm{mg}^{\mathrm{Kg}}{ }^{-1}\right)$ detected in lactic-acid bacteria plate isolated from Gorgonzola-type cheese production

\begin{tabular}{|c|c|c|c|c|c|c|c|}
\hline \multirow{2}{*}{ BATCHES } & \multirow{2}{*}{ BA } & \multicolumn{6}{|c|}{ STEPS } \\
\hline & & 1 & 2 & 3 & 4 & 5 & 6 \\
\hline \multirow{6}{*}{1} & cadaverine & $0.01^{\mathrm{a}} \pm 0.01$ & n.d. & $0.01^{\mathrm{a}} \pm 0.01$ & n.d. & $0.10^{\mathrm{a}} \pm 0.07$ & $0.10^{\mathrm{a}} \pm 0.07$ \\
\hline & spermidine & $0.02^{\mathrm{a}} \pm 0.01$ & $0.03^{\mathrm{a}} \pm 0.08$ & $0.04^{\mathrm{a}} \pm 0.02$ & $0.07^{\mathrm{a}} \pm 0.01$ & $0.61^{\mathrm{a}} \pm 1.01$ & $0.65^{\mathrm{a}} \pm 1.08$ \\
\hline & spermine & $0.03^{b} \pm 0.01$ & $0.03^{b} \pm 0.01$ & $0.05^{b} \pm 0.03$ & $0.06^{b} \pm 0.04$ & $0.07^{b} \pm 0.01$ & $0.15^{b} \pm 0.01$ \\
\hline & histamine & $0.01^{\mathrm{a}} \pm 0.01$ & $1.31^{\mathrm{a}} \pm 1.22$ & $1.77^{\mathrm{a}} \pm 1.45$ & $2.59^{\mathrm{a}} \pm 2.24$ & $2.79^{\mathrm{a}} \pm 2.40$ & $3.24^{\mathrm{a}} \pm 0.46$ \\
\hline & putrescine & $0.05^{a} \pm 0.04$ & $0.06^{\mathrm{a}} \pm 0.01$ & $0.13^{\mathrm{a}} \pm 0.06$ & $0.14^{\mathrm{a}} \pm 0.17$ & $0.17^{\mathrm{a}} \pm 0.08$ & $4.41^{\mathrm{a}} \pm 7.56$ \\
\hline & tiramine & $0.04^{\mathrm{a}} \pm 0.01$ & $0.17^{\mathrm{a}} \pm 0.01$ & $0.32^{a} \pm 0.38$ & $53.52^{\mathrm{a}} \pm 5.71$ & $120.60 \mathrm{a} \pm 87.79$ & $121.58^{\mathrm{a}} \pm 88.66$ \\
\hline \multirow{6}{*}{2} & cadaverine & n.d. & $0.01^{a b} \pm 0.01$ & $0.01^{a b} \pm 0.01$ & $0.02^{\mathrm{ab}} \pm 0.01$ & $0.03^{\mathrm{ab}} \pm 0.01$ & $0.04^{\mathrm{a}} \pm 0.02$ \\
\hline & spermidine & $0.02^{\mathrm{a}} \pm 0.01$ & $0.02^{\mathrm{a}} \pm 0.01$ & $0.02^{\mathrm{a}} \pm 0.01$ & $0.03^{\mathrm{a}} \pm 0.01$ & $0.04^{\mathrm{a}} \pm 0.02$ & $0.08^{\mathrm{a}} \pm 0.10$ \\
\hline & spermine & $0.06^{\mathrm{a}} \pm 0.02$ & $0.06^{\mathrm{a}} \pm 0.02$ & $0.10^{\mathrm{a}} \pm 0.02$ & $0.11^{\mathrm{a}} \pm 0.09$ & $0.13^{a} \pm 0.04$ & $0.13^{\mathrm{a}} \pm 0.08$ \\
\hline & histamine & $0.14^{\mathrm{a}} \pm 0.02$ & $0.59^{\mathrm{a}} \pm 0.08$ & $0.67^{\mathrm{a}} \pm 0.09$ & $2.17^{\mathrm{a}} \pm 3.61$ & $2.20^{\mathrm{a}} \pm 1.88$ & $2.87^{\mathrm{a}} \pm 2.41$ \\
\hline & putrescine & $0.06^{c} \pm 0.03$ & $0.08^{c} \pm 0.03$ & $0.09^{c} \pm 0.02$ & $0.57^{\mathrm{c}} \pm 0.97$ & $19.12^{\mathrm{b}} \pm 0.54$ & $41.52^{\mathrm{a}} \pm 1.49$ \\
\hline & tiramine & $0.42^{b} \pm 0.03$ & $3.09^{b} \pm 0.63$ & $3.78^{b} \pm 0.55$ & $19.67^{\mathrm{ab}} \pm 1.77$ & $19.86^{\mathrm{ab}} \pm 1.65$ & $34.69^{a} \pm 27.13$ \\
\hline \multirow{6}{*}{3} & cadaverine & $0.01^{\mathrm{a}} \pm 0.01$ & $0.02^{\mathrm{a}} \pm 0.02$ & $0.02^{\mathrm{a}} \pm 0.02$ & $0.03^{\mathrm{a}} \pm 0.03$ & $0.03^{\mathrm{a}} \pm 0.03$ & $0.05^{\mathrm{a}} \pm 0.03$ \\
\hline & spermidine & $0.01^{\mathrm{a}} \pm 0.01$ & $0.01^{\mathrm{a}} \pm 0.01$ & $0.01^{\mathrm{a}} \pm 0.01$ & $0.04^{\mathrm{a}} \pm 0.02$ & $0.04^{\mathrm{a}} \pm 0.05$ & $0.04^{\mathrm{a}} \pm 0.05$ \\
\hline & spermine & $0.01^{\mathrm{a}} \pm 0.02$ & $0.20^{\mathrm{a}} \pm 0.21$ & $0.07^{\mathrm{a}} \pm 0.04$ & $0.07^{\mathrm{a}} \pm 0.06$ & $0.07^{\mathrm{a}} \pm 0.06$ & $0.09^{\mathrm{a}} \pm 0.06$ \\
\hline & histamine & $0.03^{\mathrm{a}} \pm 0.01$ & $0.07^{\mathrm{a}} \pm 0.02$ & $0.09^{\mathrm{a}} \pm 0.06$ & $0.15^{\mathrm{a}} \pm 0.07$ & $0.15^{\mathrm{a}} \pm 0.07$ & $0.56^{\mathrm{a}} \pm 0.81$ \\
\hline & putrescine & $0.03^{\mathrm{a}} \pm 0.04$ & $0.04^{\mathrm{a}} \pm 0.06$ & $0.05^{\mathrm{a}} \pm 0.69$ & $0.07^{\mathrm{a}} \pm 0.11$ & $0.12^{\mathrm{a}} \pm 0.15$ & $0.12^{\mathrm{a}} \pm 0.15$ \\
\hline & tiramine & $0.01^{\mathrm{a}} \pm 0.01$ & $0.01^{\mathrm{a}} \pm 0.01$ & $0.10^{\mathrm{a}} \pm 0.12$ & $0.39^{\mathrm{a}} \pm 0.09$ & $9.59^{\mathrm{a}} \pm 10.38$ & $9.59^{\mathrm{a}} \pm 10.38$ \\
\hline
\end{tabular}

Means of determinations with standard deviation. Values in the same rows with different letters are significantly different ( $p$ < 0.05). Steps: (1) milk, (2) culture addition, (3) curd, (4) dry salting, (5) 30 days of maturation, and (6) 60 days of maturation. Legend: BA - Biogenic Amine; n.d. - not detected.

these values are more than double to the values found in three batches of Gorgonzola-type cheese manufactured of this article.

Ubaldo et al. (2015) quantified the maximum level of tyramine in Muzzarella-type cheese at $28.04 \mathrm{mg} \cdot \mathrm{Kg}^{-1}$.

Cheese represents an ideal environment for the production of amines and matured cheeses are more prone to amine formation. In fact, several outbreaks of histamine poisoning have been reported and associated with the consumption of some cheeses (Buňková et al., 2010). In addition, the presence and accumulation of some amines in the cheese may be an indication of inadequate manufacturing and milking practices (Buňková et al., 2010; EFSA, 2011).

All events were observed because the initial raw material showed a high initial level of contaminating bacteria with the ability to decarboxylate amino acids and produce biogenic amines. This fact is confirmed by the high production of BA throughout the maturation process. The results were different from the other findings of the articles because in other countries, there is a greater rigor in terms of milk quality, in terms of possible contamination during handling and in the choice of safe bacterial strains of cultures.

\section{Conclusions}

It is concluded that, cheese still remains a more perfect and complete medium for the observation of development of microorganisms and BA formation.

Regarding the appearance of BA, the choice of a special starter culture and lack of BA formation capacity associated with good manufacturing and milking practices would lead to better results when compared with the use of simple cultures and usual methods of manufacturing and milk conservation. Therefore, the use of greater stringency in the choice of starter culture and greater control in the appearance of BA in cheeses could be a criterion of quality in the manufacture of matured cheeses to obtain positive effects in the non-formation of BA or the retardation of their formation.

It is needed to establish limits for the other BA, since, in Brazilian legislation, there is only for histamine. They should be used as a quality criterion because, when present, they can remain in the final product even after long periods of maturation and cause serious and silent damage to consumer health.

\section{Acknowledgments}

The authors are grateful for financial support from CAPES (Coordination of Improvement of Higher Education Personnel) and the Foundation for Research Support of the State of Rio de Janeiro (FAPERJ) for their support through projects E-26/103.003/2012 and E-26/112.393/2012. SANTOS was supported by the Coordination for Higher-Level Training (CAPES). 


\section{Referências}

ANDIC, S.; GENCCELEP, H.; KOSE S. Determination of biogenic amines in Herby cheese. International Journal of Food Properties, v. 13, p, 1300-1314, 2010.

AOAC. Official Methods of Analysis. 18th ed. Washington, DC, USA: Association of Official Analytical Chemists; 2005.

APHA. Compendium of Methods for the Microbiological Examination of Foods. 4th ed. Washington, DC: American Public Health Association; 2001.

BRASIL. Instrução Normativa SDA n 62, de 26 de agosto de 2003. Oficialização dos Métodos Analíticos Oficiais para Análises Microbiológicas para Controle de Produtos de Origem Animal e Água, com seus respectivos capítulos e anexos, em conformidade com o anexo desta Instrução Normativa, determinando que sejam utilizados no Sistema de Laboratório Animal do Departamento de Defesa Animal. Diário Oficial da União, Brasília, DF, p. 14, 18 set. 2003. Seção 1.

BUŇKOVÁ, L.; BUŇKA, F.; MANTLOVÁ, G.; ČABLOVÁ, I.S.; SEDLÁČEK, I.; ŠVEC, P.; PACHLOVÁ, V.; KRÁCMAR, S. The effect of ripening and storage conditions on the distribution of tyramine, putrescine and cadaverine in Edam-cheese. Food Microbiology, v.27, p.880-888, 2010.

BUŇKOVÁ, L.; ADAMCOVÁ, G.; HUDCOVÁ, K.; VELICHOVÁ, H.; PACHLOVÁ, V.; LORENCOVÁ, E.; BUŇKA, F. Monitoring of biogenic amines in cheeses manufactured at small- scale farms and in fermented dairy products in the Czech Republic. Food Chemistry, v.141, p.548-551, 2013.

CERUTTI, G.; CECCHI, L.; BRASCA, M.; MANERA, E.; PAITA, F. Biogenesis of amines in storage of cheese. Rivista Di Scienza Dell'Alimentazione, v.23, n.4, p.441-452, 1994.

COSTA, M.P.; BALTHAZAR, C. F.; RODRIGUES, B.L.; LAZARO, C.A. SILVA, A.C.O. CRUZ, A.G.; CONTE JUNIOR, C.A. Determination of biogenic amines by high-performance liquid chromatography (HPLC-DAD) in probiotic cow's and goat's fermented milks and acceptance. Food Science and Nutrition, n. 3, v. 3, p. $172-178,2015$

CUNHA, F.L.; CONTE-JUNIOR, C.A.; LÁZARO, C.A.; SANTOS, L.R.; MÁRSICO, E.T.; MANO, S.B. Determinação de aminas biogênicas em diferentes tipos de queijos por cromatografia líquida de alta eficiência. Revista Instituto Adolfo Lutz, v.71, p.6975, 2012.

DAHL, S.; TAVARIA, F.K.; MALCATA, F.X. Relationship between flavour and microbiological profiles in Serra da Estrela cheese throughout ripening. International Dairy Journal, v.10, p. 255-262, 2000.

DANNENHAUER, C.E. Desenvolvimento de um Aplicativo Computacional para Microbiologia Preditiva. Dissertação (Mestrado em Engenharia de Alimentos) - Centro Tecnológico, Universidade Federal de Santa Catarina, Florianópolis, 147p. 2010.

DAVIS, J.G. The use of Special Litmus Milk Media for the Diagnostic Culture of Lactic Acid Bacteria: (1) Dextrose Litmus Milk, (2) Yeast Extract Litmus Milk, and (3) Yeast Extract Dextrose Litmus Milk. Journal of Dairy Research, v.6, p.121-124, 1935.

DEL RIO, B.; REDRUELLO, B.; LINARES, D.M.; LADERO, V.; FERNANDEZ, M.; MARTIN, M.C.; RUAS-MADIEDO, P.; ALVAREZ, M.A. The dietary biogenic amines tyramine and histamine show synergistic toxicity towards intestinal cells in culture. Food Chemistry, v.218, p.249-255, 2017.
DIEZHANDINO, I.; FERNÁNDEZ, D.; GONZÁLEZ, L.; MCSWEENEY, P.L.H.; FRESNOA, J.M. Microbiological, physicchemical and proteolytic changes in a Spanish blue cheese during ripening (Valdeón cheese). Food Chemistry, v.168, p.134-141, 2015. EFSA (European Food Safety Authority e Panel on Biological Hazards - BIOHAZ). Scientific opinion on risk based control of biogenic amine formation in fermented foods. EFSA Journal, v.9, p.2393, 2011.

EL-SHEIKH, M.M.; EL-SENAITY, M.H.; YOUSSEF, Y.B.; SHAHEIN, N.M.; ABD RABOU, N.S. Effect of ripening conditions on the properties of Blue cheese produced from cow's and goat's milk. Journal of American Science, v.7, n.1, p. 485-490, 2011.

FILIPELLO, V.; GALLINA, S.; AMATO, E.; LOSIO, M.N.; PONTELLO, M.; DECASTELLI, L.; LOMONACO, S. Diversity and persistence of Listeria monocytogenes within the Gorgonzola PDO production chain and comparison with clinical isolates from the same area. International Journal of Food Microbiology, v. 245, p. 73-78, 2017.

GALITSOPOULOU, A.; MICHAELIDOU, A-M.; MENEXES, G.; ALICHANIDIS, E. Polyamine profile in ovine and caprine colostrum and milk. Food Chemistry, v. 173, p. 80-85, 2015.

GILLOT, G.; JANY, J-L.; POIRIER, E.; MAILLARD, M-B.; DEBAETS, S.; THIERRY, A.; COTON, E. Funcional diversity within the Penicillium roqueforti species. International Journal of Food Microbiology, v.241, p.141-150, 2017.

GOMES, M.B.; PIRES, B.A.D.; FRACALANZZA, S.A.P.; MARIN, V.A. O risco das aminas biogênicas. Ciência e Saúde Coletiva, v. 19, n. 4, p. 1123-1134, 2014. Disponível em: <http://www.scielo.br/ scielo.php?script=sci_arttext\&pid=S1413-81232014000401123>. Acesso em: 01 abr. 2017.

HALÁSZ, A.; BARÁTH, Á.; SIMON-SARKADI, L.; HOLZAPFEL, $W$. Biogenic amines and their production by microorganisms in food. Trends in Food Science and Technology, v.5, 1994.

HERMANNS, G.; FUNCK, G.D.; SCHIMIDT, J.T.; RICHARDS, N.S.P.S. Isolation and identification of supposedly bacteriocinogenic lactic acid bacteria from milk and cheese. Revista Acadêmica: Ciências Agrárias Ambientais, v.11, n.2, p.191-196, 2013.

HERNANDEZ-JOVER, T.; IZQUIERDO-PULIDO, M.; VECIANANOGUES, M.T.; MARINE-FONT, A.E.; VIDAL-CAROU, M.C. Biogenic amines and polyamine contents in meat and meat products. Journal of Agricultural and Food Chemistry, v.45, p.2098-2102, 1997.

HERRERO-FRESNO, A.; MARTÍNEZ, N.; SÁNCHEZ-LLANA, E.; DÍAZ, M.; FERNÁNDEZ, M.; MARTIN, M.C.; LADERO, V.; ALVAREZ, M.A. Lactobacillus casei strains isolated from cheese reduce biogenic amine accumulation in an experimental model. International Journal of Food Microbiology, v.157, p.297-304, 2012.

IZQUIERDO, P.; ALLARA, M.; TORRES, G.; GARCÍA, A.; BARBOZA, Y.; PIÑERO, M.I. Histamina en quesos madurados: Manchego, Parmesano y De Año. Revista Científica, v.3, p.431435, 2003.

LADERO, V.; LINARES, D.M.; FERNÁNDEZ, M.; ALVAREZ, M.A. Real time quantitative PCR detection of histamine-producing lactic bacteria in cheese: Relation with histamine content. Food Research International, v.41, n.10, p.1015-1019, 2008.

LÁZARO, C.A.; CONTE-JÚNIOR, C.A.; CUNHA, F.L.; MÁRSICO, E.T.; MANO, S.B.; FRANCO, R.M. Validation of an HPLC Methodology for the identification and quantification of biogenic amines in chicken meat. Food Analytical Methods, v.6, p.10241032, 2013. 
LAW, B.A.; TAMIME, A. Y. Technology of cheesemaking. Sussex: Wiley-Blackwell, 515 p.2010.

MISHRA, V.; SHAH, C.; MOKASHE, N.; CHAVAN, R.; YADAV, H.; PRAJAPATI, J. Probiotics as potential antioxidants: A systematic review. Journal of Agricultural and Food Chemistry, v.63, p.36153626, 2015.

MISTRY, V.V. The effects of milk, its ingredients and salt on cheese flavor. In: B.C. Weimer, editor, Improving the flavour of cheese. Woodhead Publishing, Cambridge, GBR. p. 239-251, 2007.

MONTANHA, A.A.O. Aminas biogênicas e polifenóis no leite e queijo de ovelhas da raça bergamácia suplementadas com óleo ou farelo de linhaça (Linum usitassimum L.). Botucatu, 2016. 68f. Tese (Doutorado em Zootecnia) - Faculdade de Medicina Veterinária e Zootecnia, |Universidade Estadual Paulista, Botucatu, 2016.

MORAES, J.M.; FREITAS, L.C.G. Adaptação da tecnologia de fabricação de queijos de origem italiana - queijo Gorgonzola. Revista do Instituto de Laticínio Cândido Tostes, v.38, n.227, p.33-39, 1983.

MORET, S.; BORTOLOMEAZZI, R.; FERUGLIO, M.; LERCHER, G. Determination of biogenic amines in Italian cheeses. Scienza e Tecnica Lattiero-Casearia, v.43, p.187-198, 1992.

ÖZDESTAN Ö.; ÜREN A. Biogenic amine content of kefir: a fermented dairy product. European Food Research and Technology, v.231, p.101-107, 2010.

PRIYADARSHANI, W.M.D.; RAKSHIT, S.K. Screening selected strains of probiotic lactic acid bacteria for their ability to produce biogenic amines (histamine and tyramine). International Journal of Food Science and Technology, v.46, p.2062-2069, 2011.

QURESH, T.M.; VERMEER, C.; VEGARUD, G.E.; ABRAHAMSEN, R.K.; SKEIE, S. Formation of biogenic amines and vitamin $\mathrm{K}$ contents in the Norwegian autochthonous cheese Gamalost during ripening. Dairy Science \& Technology, v.93, p.303-314, 2013.

RAMÍREZ-NAVAS, J.S.; AGUIRRE-LONDOÑO, J.; ARISTIZABALFERREIRA, V.A.; CASTRO-NARVÁEZ, S. La sal em queso: diversas interacciones. Agronomia Mesoamericana, v.28, n.1, p.303-316, 2017.
RASOVIC, M.B.; MAYRHOFER, S.; MARTINOVIC, A.; DÜRR, K.; DOMIG, K.J. Potential lactococcal starter cultures for Montenegrin cheese. Food Technology and Biotechnology, n.55, v.1, p.55-66, 2017.

RIQUEIRA, J. C. S. Influência da contagem de células Somáticas no perfil e teores de aminas Bioativas e na qualidade de leite cru e de queijo mussarela. 2010. 147p. Tese (Doutorado em Ciência de Alimentos) - Faculdade de Farmácia, Universidade Federal de Minas Gerais, Belo Horizonte.

RODRIGUEZ, J. Recent advances in the development of low-fat cheeses. Trends in Food Science \& Technology, v.9, p.249-254, 1998.

RODRÍGUEZ, F.P.; POSADA-IZQUIERDO, G.D.; VALERO, A.; GARCÍA-GIMENO, R.M.; ZURERA, G. Modelling survival kinetics of Staphylococcus aureus and Escherichia coli O157:H7 on stainless steel surfaces soiled with different substrates under static conditions of temperature and relative humidity. Food Microbiology, v.5, n.2, p.197-204, 2013.

SCHIRONE, M.; TOFALO, R.; FASOLI, G.; PERPETUINI, G.; CORSETTI, A.; MANETTA, A.C.; CIARROCCHI, A.; SUZZI, G. High contente of biogenic amines in Pecorino cheeses. Food Microbiology, v.34, p.137-144, 2013.

SERIO, A.; CHAVES-LÓPEZ, C.; PAPARELLA, A.; CORSETTI, A.; MARTINO, G.; SUZZI, G. Microbiological and physico-chemical characterization of Pecorino Abruzzese cheese during ripening. In Proceedings of Technological Innovation and Enhancement of Marginal Products, Foggia, Italy. Journal of Applied Microbiology, p.6-8, 2006.

SPIZZIRRI, U.G.; RESTUCCIA, D.; CURCIO, M.; PARISI, O.I.; IEMMA, F.; PICCI, N. Determination of biogenic amines in different cheese samples by LC with evaporative light scattering detector. Journal of Food Composition and Analysis, v.29, p.43-51, 2013.

STRATTON, J.; HUTKINS, R.; SUMNER, S.; TAYLOR, S. Histamine and Histamine Producing Bacteria in Retail Swiss and Low Salt Cheeses. Journal of Food Protection, v.55, p.435-439, 1992.

URBACH, G. Contribuition of lactic acid bacteria to flavour compound formation in dairy products. International Dairy Journal, v.5, p.877-903, 1995. 